Acta Protozool. (2017) 56: 161-169

www.ejournals.eu/Acta-Protozoologica

doi:10.4467/16890027AP.17.014.7495

PROTOZOOLOGICA

\title{
Taxonomical reinvestigation of the colepid species Pinacocoleps pulcher (Spiegel, 1926) Foissner et al., 2008 (Ciliophora: Prorodontida: Colepidae)
}

\author{
Ji Hye MOON, *, Ji Hye KIM", *, Jae-Ho JUNG ${ }^{1}$ \\ ${ }^{1}$ Department of Biology, Gangneung-Wonju National University, Gangneung, South Korea; ${ }^{2}$ Natural Science Research Institute, \\ Gangneung-Wonju National University, Gangneung, South Korea \\ ${ }^{*}$ Both authors contributed equally to this study.
}

\begin{abstract}
Brackish water populations of Pinacocoleps pulcher were collected from a lagoon in Korea. This species has never been described using silver impregnation and nuclear small subunit ribosomal RNA (SSU rRNA) gene. In the present study, we investigated the morphological and molecular attributes of $P$. pulcher using standard methods. The morphology was studied based on observations of live materials, silver-impregnated preparations, and scanning electron microscopy. The morphological characteristics are as follows: body size 80-90 $\times 40-50 \mu \mathrm{m}$ in vivo, shape broadly ellipsoidal, body cross-section ellipsoidal, about seven anterior spines and about seven posterior spines, approximately 21 somatic ciliary rows, one macronucleus and one micronucleus, and a single caudal cilium. The SSU rRNA gene tree supports a sister relationship of $P$. pulcher to the genus Apocoleps, not $P$. tesselatus.
\end{abstract}

Keywords: ciliate, redescription, taxonomy, SSU rDNA sequences, brackish water, Korea.

\section{INTRODUCTION}

Pinacocoleps Diesing, 1865 had long been forgotten until Foissner et al. (2008) resurrected it. Diesing (1865) defined Pinacocoleps as a genus with longitudinal and transversal grooves on the plates. Foissner et al. (2008) refined Pinacocoleps with six tiers and incurvus-type (currently Pinacocoleps-type) plates. Foissner et al. (2008) and Chen et al. (2010) assigned seven species to Pinacocoleps ( $\mathrm{Lu}$ et al. 2013). Of these, only two species were described morphologically using stand-

Address for correspondence: Jae-Ho Jung, Department of Biology, Gangneung-Wonju National University, Gangneung, South Korea; Fax: +82-33-640-2867; E-mail: jhjung@gwnu.ac.kr ard methods (P. similis and P. tesselatus), and only one SSU rRNA gene sequence of $P$. tesselatus is available (Chen et al. 2010; Lu et al. 2013). Therefore, this study provides the redescription of $P$. pulcher and the SSU rRNA gene tree of Colepidae Ehrenberg, 1838 including the newly sequenced SSU rRNA gene sequences of P. pulcher.

\section{MATERIALS AND METHODS}

\section{Sample collection and identification}

Pinacocoleps pulcher was collected from Songiho lagoon in Goseong, Korea in June 2016 (salinity 15\%o, 38 20’09.21" N, $128^{\circ} 30^{\prime} 57.62^{\prime \prime} \mathrm{E}$ ) and September 2017 (salinity 9.6\%o, 38 20’09.40" N, 
$\left.128^{\circ} 30^{\prime} 57.80^{\prime \prime} \mathrm{E}\right)$. The water samples including the stirred sandy sediment were collected from the marginal sides of lagoon and transferred to a laboratory. The samples were cultured with rice grains and maintained at room temperature. Living cells were observed under a dissecting microscope (Olympus SZ61, Japan) and an optical microscope (Olympus BX53, Japan) using differential interference contrast at low $(50-200 \times)$ to high $(400-1000 \times)$ magnification. The ciliature was revealed using protargol impregnation (Foissner 2014). Protargol preparations were made from the specimens collected in June, 2016. The protargol powder was manually synthesized (Pan et al. 2013). We followed terminology and systematics of Foissner et al. (2008), Lynn (2008), Chen et al. (2010), and Lu et al. (2013).

\section{Scanning electron microscopy}

We mainly followed the protocol 'Preparation for scanning electron microscopy (SEM)' (Foissner 2014). The live cells, collected in September 2017, were washed about three times in distilled water and air-dried on a poly-L-lysine coated cover slip. The cover slip was transferred a coater and a field emission SEM (FEI Inspect F; USA).

\section{DNA extraction, PCR amplification, and sequencing}

Single cell was isolated using a microcapillary from the cultural dish and transferred to distilled water. The genomic DNA was extracted using a REDExtract-N-Amp Tissue PCR Kit (Sigma, St. Louis, MO, US) according to the manufacturer's protocol. Amplification of the SSU rRNA gene was performed using two primers New Euk A (5'-CTG GTT GAT YCT GCC AGT-3') and Euk B (5'-TGA TCC TTC TGC AGG TTC ACC TAC-3'). The conditions were as follows: denaturation at $94^{\circ} \mathrm{C}$ for $90 \mathrm{~s}$, followed by $40 \mathrm{cy}-$ cles of denaturation at $98^{\circ} \mathrm{C}$ for $10 \mathrm{~s}$, annealing at $58.5^{\circ} \mathrm{C}$ for $30 \mathrm{~s}$, and extension at $72^{\circ} \mathrm{C}$ for $2 \mathrm{~min}$, and a final extension step at $72^{\circ} \mathrm{C}$ for $7 \mathrm{~min}$. MEGAquick-spin ${ }^{\mathrm{TM}}$ Total Fragment DNA Purification Kit (iNtRON, Korea) was used to purify the PCR products. Two internal primers (18SF790v2: 5'-AAA TTA KAG TGT TYM ARG CAG-3' and 18SR300: 5'-CAT GGT AGT CCA ATA CAC TAC-3') were additionally used for sequencing. DNA sequencing was performed using an ABI 3700 sequencer (Applied Biosystems, Foster City, US). These specimens collected in 2016 and 2017 have the identical DNA sequence.

\section{Phylogenetic analyses}

SSU rRNA gene sequences of 17 colepid species and one Prorodon (as an outgroup) were retrieved from the NCBI database. The nucleotide sequence of Pinacocoleps pulcher was assembled using Geneious 9.1.5 (Kearse et al. 2012), and the 19 sequences were aligned and trimmed with BioEdit 7.0.9.0. The substitution model for phylogenetic analyses was GTR + I (0.6080) + G (0.5710) model under Akaike information criterion (AIC) using jModelTest 2.1.7 (Darriba et al. 2012). The Bayesian inference tree was inferred using MrBayes 3.1.2 (Ronquist et al. 2012) and 1,000,000 generations were carried out with Markov chain Monte Carlo (MCMC), and 300,000 generations were removed as burnin. Moreover, the maximum likelihood tree was constructed using IQ-Tree 1.5.3 (Nguyen et al. 2015) with 1,000 replicates using the ultrafast bootstrap approximation approach. Pairwise distances were calculated using Mega 6.06 (Tamura et al. 2011).

\section{RESULTS}

\section{Pinacocoleps pulcher (Spiegel, 1926) Foissner et al., 2008 (Figs 1-3; Table 1)}

1926 Coleps pulcher Spiegel, Arch. Protistenkd., 55: 188, Fig. D.

1930 Coleps pulcher: Kahl, Tierwelt Dtl., 18: 136, Fig. 19: 18, 19.

1937 Coleps pulcher: Noland, Trans. Am. Microsc. Soc. 56: 161, Fig. 1D, E (brief description).

1963 Coleps pulcher: Borror, Arch. Protistenk. 106: 480, Fig. 31, 32.

1973 Coleps pulcher: Hartwig, Akad. Wiss. Mainz. Mikrofauna Meer. 18: 12, Fig. 2A.

2008 Pinacocoleps pulcher: Foissner, Kusuoka and Shimano, 2008, J. Eukaryot. Microbiol. 55: 198 (new combination).

\section{Improved diagnosis}

Habitat brackish to marine; body size 70-110 × 30-60 $\mu \mathrm{m}$ in vivo, body shape pillow-like; body-cross section ellipsoidal; about 21 ciliary rows; about 18 transverse circles; one macronucleus and one micronucleus; about seven anterior and seven posterior spines; smooth plate ridge; window absent; one caudal cilium; Pinacocolepstype plate.

\section{Deposition of voucher slides}

Two protargol-impregnated voucher slides were deposited in Natural Institute of Biological Resources (NIBR), Incheon, South Korea with registration numbers (NIBRPR0000107199, NIBRPR0000107200). The other three voucher slides (MABIK PR00042795MABIK PR00042797) have been deposited in the National Marine Biodiversity Institute of Korea (MABIK), South Korea.

\section{Description of Korean Population}

Pinacocoleps pulcher has a body size of 80-90 $\times$ $40-50 \mu \mathrm{m}$ in vivo, which is pillow-like and roughly rectangular, and the length:width ratio is approximately $1.5: 1$ in protargol preparations, and $2: 1$ in vivo. A crown-like apical end is caused by the protruded secondary tier plates, and the posterior end is broadly rounded (Table 1; Fig. 1A, C; 2A-E, I; 3A). The body is laterally flattened and the cross-section of the body is ellipsoidal (Table 2; Fig. 1C, F; 2E, K). The main armor plates abut in the weakly indented midbody (Fig. 1A-C; 2A, B; 3A). A globular to slightly 
ellipsoidal macronucleus is located irregularly in the cytoplasm, and its average size is $9.1 \times 7.7 \mu \mathrm{m}$, with an average length:width ratio of $1.2: 1$ in the preparations (Table 1; Fig. 1A, G; 2I). An ellipsoidal micronucleus is located near the macronucleus and size approximately $2.1 \times 1.7 \mu \mathrm{m}$ after prepared (Table 1; Fig. 1A, G; 2I) Contractile vacuole is located posterior end of the cell (Fig. 1A; 2D).

The armor belongs to the Pinacocoleps-type plate (for details of the types, see Chen et al. 2010) and consists of six kinds of tiers: circumoral tier, anterior secondary tier, anterior main tier, posterior main tier, posterior secondary tier, and caudal tier. The plates are colorless, rigid, and can be split under strong coverslip pressure (Fig. 1A, B; 2A-D, F-H). The circumoral and caudal tiers are usually unrecognizable in vivo. The circumoral plates are roughly rectangular with small spines (Fig. 1B; 3E). The anterior secondary plates are triangular, and the apical ends of each of these plates protrude acutely beyond the circumoral tiers to provide a crown-like appearance; each plate contains three teeth and two ciliary outlets, and two of them have anterior spines (Fig. 1A, B; 2B, C; 3A, C-E). The anterior and posterior main plates are rectangular; these main plates on each lateral side contain three anterior spines and one posterior spine, respectively (Fig. 1A, $\mathrm{B} ; 2 \mathrm{~B}, \mathrm{G} ; 3 \mathrm{~A}, \mathrm{D}, \mathrm{G})$. The number of teeth in the anterior and posterior main plates is approximately eight and seven, respectively (Table 2). The posterior secondary plates are approximately triangular, with two teeth and two ciliary outlets. The posterior secondary plates and caudal plates include six to ten posterior spines (on av- erage seven), including four to six dominant spines on the lateral sides and three or four spines on caudal tier plates (Fig. 1A, B; 2A, B, H; 3A, B, F). Each plate has basically smooth surface; circular grooves are regularly distributed on right side and about $0.1 \mu \mathrm{m}$ in diameter; pores/grooves are irregularly located on left side and $0.1-0.6 \times 0.1-0.7 \mu \mathrm{m}$ in SEM; windows are absent, the ridges are located centrally, and the left margin of the plates are slightly serrated (Fig. 1A, B; 2F-H; 3A-G).

Somatic ciliary rows are indistinct in the preparations because of the strongly impregnated silverlines (Fig. 2I-K). Approximately 21 longitudinal rows are present between each silverlines; 18 transverse rows (Table 1; Fig. 1E-G; 2I, K). The parasomal sac (Fig. 1E, arrow) is associated with a somatic monokinetid (Fig. 1E, G, arrowhead) and located obliquely below the kinetid (Fig. 1E, G; 2I). Tiny pores are located beside each ciliary outlet (Fig. 1E; 2I). The oral opening is at the apical end of the cell (Fig. 1D, G; 2J). The circumoral kinety surrounding the oral opening is interrupted by three obliquely arranged adoral organelles. Each of these organelles consists of four monokinetids (Fig. 1D, G; 2J). The perioral ciliature, which surrounds the outer side of the circumoral kinety, is composed of two dikinetids that connect to the anterior part of each somatic kineties (Fig. 1D, G; 2J). The oral basket is inconspicuous in vivo, but distinct in preparations. Each pharyngeal fiber is approximately $8 \mu \mathrm{m}$ in length. Somatic cilia are about $10 \mu \mathrm{m}$ long in vivo. One caudal cilium, located in the central part of the rear end, is approximately $25 \mu \mathrm{m}$ in length (Fig. 1A, F; $2 \mathrm{~K}$ ).

Table 1. Morphometric characteristics of Pinacocoleps pulcher based on protargol impregnated and SEM specimens.

\begin{tabular}{|c|c|c|c|c|c|c|c|c|}
\hline Character & Min & $\operatorname{Max}$ & Mean & Med & $\mathrm{SD}$ & $\mathrm{SE}$ & $\mathrm{CV}$ & $\mathrm{n}$ \\
\hline Body length $(\mu \mathrm{m})$ & 60 & 77 & 67.5 & 65.5 & 4.3 & 0.9 & 6.4 & 21 \\
\hline Body width $(\mu \mathrm{m})$ & 31 & 60 & 44.4 & 44 & 7.0 & 1.5 & 15.8 & 21 \\
\hline Somatic kineties (number) & 18 & 24 & 20.9 & 21 & 1.5 & 0.3 & 7.2 & 21 \\
\hline Transverse ciliary rows (number) & 17 & 20 & 18.0 & 18 & 0.8 & 0.2 & 4.5 & 21 \\
\hline Macronucleus, length ( $\mu \mathrm{m})$ & 7 & 12 & 9.1 & 9.5 & 1.3 & 0.3 & 14.5 & 21 \\
\hline Macronucleus, width $(\mu \mathrm{m})$ & 5.5 & 10.5 & 7.7 & 8.0 & 1.2 & 0.3 & 15.5 & 21 \\
\hline Micronucleus, length $(\mu \mathrm{m})$ & 1 & 3.5 & 2.1 & 2.5 & 0.7 & 0.2 & 31.5 & 15 \\
\hline Micronucleus, width $(\mu \mathrm{m})$ & 1 & 3 & 1.7 & 1.5 & 0.5 & 0.1 & 31.4 & 15 \\
\hline Oral opening, length $(\mu \mathrm{m})$ & 6.5 & 9.5 & 8.0 & 8.0 & 0.9 & 0.2 & 11.6 & 21 \\
\hline Anterior spines (number)* & 5 & 10 & 7.0 & 7 & 1.6 & 0.5 & 22.3 & 10 \\
\hline Posterior spines (number)* & 4 & 10 & 6.8 & 7 & 1.7 & 0.5 & 24.8 & 10 \\
\hline
\end{tabular}

* Data from SEM. Abbreviations: CV - coefficient of variation (\%), Max - maximum, Min - minimum, SD - standard deviation, SE - standard error of mean, $\mathrm{n}-$ number of individuals examined. 


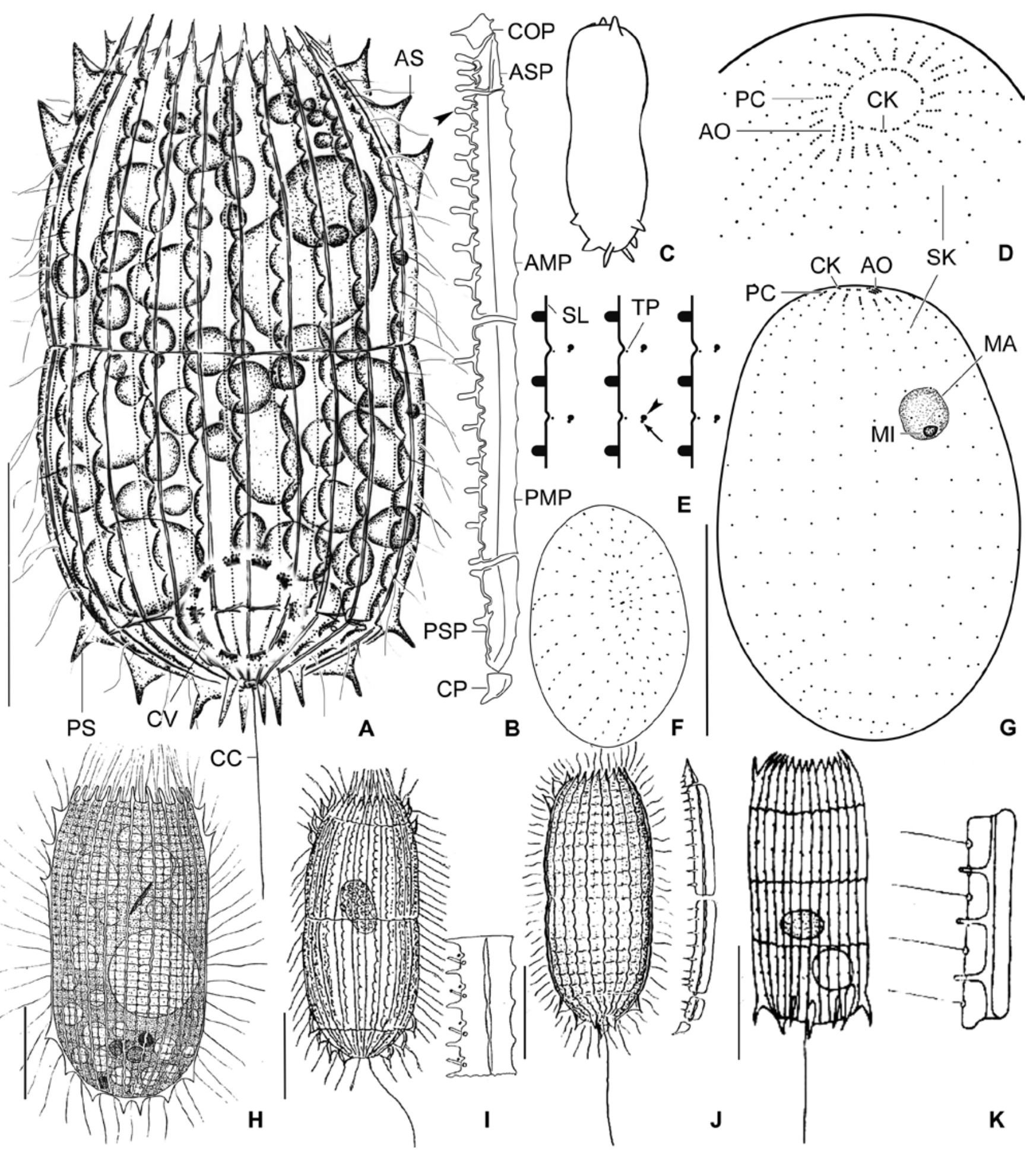

Fig. 1A-J. Morphology of Pinacocoleps pulcher (Spiegel, 1926) in vivo (A-C), protargol impregnation (D-G), previous studies (H, I), and closely related congeners (J, K). A. Broad side lateral view of a typical individual. B. Detailed structure of one row of armor plates (arrowhead denotes plate tooth). C. Slender side lateral view. D. Ciliary pattern (apical view). E. Schematic drawing of detailed somatic ciliature and silverlines (arrow indicates parasomal sac and arrowhead indicates basal body of somatic kinetid). F. Ciliary pattern (caudal view). G. Somatic ciliary rows. H, I. P. pulcher (H from Spiegel 1926; I from Kahl 1930). J. P. heteracanthus (from Noland 1937). K. P. arenarius (from Bock, 1952). AO - adoral organelles, AS - anterior spines, CC - caudal cilium, CK - circumoral kineties, COP - circumoral plate, $\mathrm{CP}$ - caudal plate, $\mathrm{CV}$ - contractile vacuole, $\mathrm{TP}$ - tiny pore, $\mathrm{Ma}$ - macronucleus, $\mathrm{Mi}$ - micronucleus, $\mathrm{PC}$ - perioral ciliature, $\mathrm{PS}$ - posterior spines, SK - somatic kineties. Scale bars: $30 \mu \mathrm{m}(\mathrm{A}, \mathrm{G}-\mathrm{K})$. 

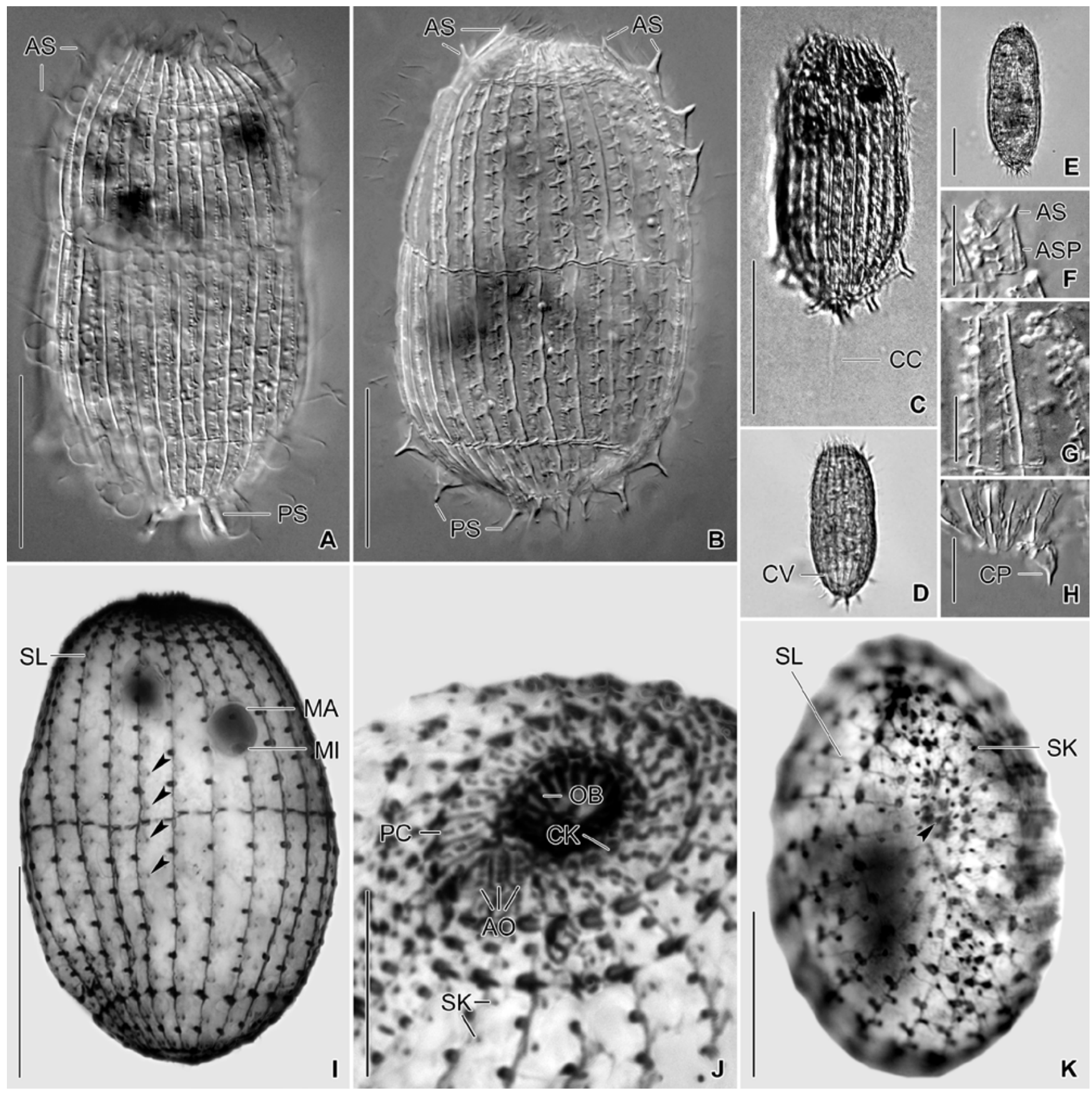

Fig. 2A-K. Photomicrographs of Pinacocoleps pulcher (Spiegel, 1926) in vivo (A-H) and after protargol impregnation (I-K). A, B. Lateral view of the broad side. C. Free swimming individual to show caudal cilium. D. Lateral view of the broad side to show contractile vacuole. E. Lateral view of the narrow side. F. Teeth of anterior second plate. G. Anterior main plate. H. Posterior second plate with a caudal plate. I. Lateral view of a typical individual (arrowheads indicate somatic ciliature). J. Apical view showing oral ciliature. K. Caudal view (arrowhead denotes basal body of caudal cilium). AMP - anterior main tier plate, AO - adoral organelles, AS - anterior spines, ASP - anterior secondary tier plate, $\mathrm{CC}$ - caudal cilium, $\mathrm{CK}$ - circumoral kineties, $\mathrm{CP}$ - caudal plate, $\mathrm{CV}$ - contractile vacuole, Ma - macronucleus, $\mathrm{Mi}$ - micronucleus, $\mathrm{OB}$ - oral basket, $\mathrm{PC}$ - perioral ciliature, PS - posterior spines, SK - somatic kineties, SL - silverline. Scale bars: $50 \mu \mathrm{m}$ (C), $30 \mu \mathrm{m}(\mathrm{A}, \mathrm{B}, \mathrm{E}, \mathrm{I}), 20 \mu \mathrm{m}(\mathrm{K}), 10 \mu \mathrm{m}(\mathrm{F}-\mathrm{H}, \mathrm{J})$. 


\section{SSU rRNA gene tree (Fig. 4)}

The SSU rRNA gene of $P$. pulcher was sequenced and the read length was 1,623 bp (GenBank accession number: MG020516). The genetic distance between P. pulcher and P. tesselatus (KC349950) was 2.8\% (44 nucleotide differences). Moreover, the genetic distance between $P$. pulcher and the other closely related species was as follows: $0.3 \%$ (five nucleotide differences) from Apocoleps magnus (FJ858213) and 0.2-0.4\% from Apocoleps sp. (three nucleotide differences; HM747137) and Apocoleps sp. (seven nucleotides differences; FJ858214).
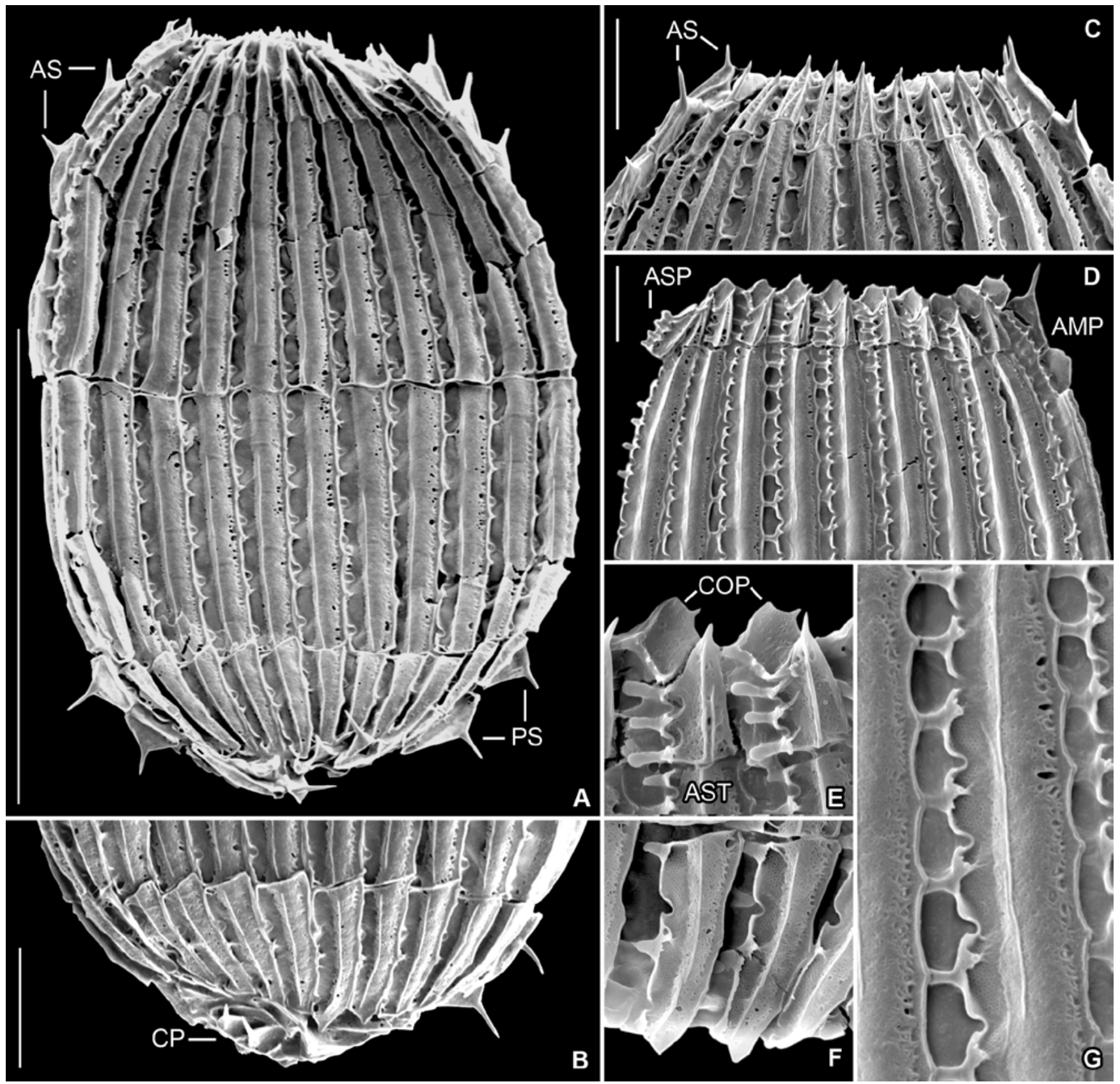

Fig. 3A-D. Scanning electron microscopy of Pinacocoleps pulcher (Spiegel, 1926). A. Lateral view of the broad side showing typical morphology. B. Posterior view showing posterior secondary plates and caudal plates. C. Anterior view showing anterior spines. D. Anterior view showing anterior main plates and anterior secondary plates. E. Anterior secondary plates and circumoral plates. F. Posterior secondary plates. G. Anterior main plates. AMP - anterior main tier plate, AS - anterior spines, ASP - anterior secondary tier plate, AST - anterior secondary plate teeth, $\mathrm{COP}$ - circumoral plate, $\mathrm{CP}$ - caudal plate, $\mathrm{PS}$ - posterior spines. Scale bars: $50 \mu \mathrm{m}(\mathrm{A}), 10 \mu \mathrm{m}(\mathrm{B}-\mathrm{G})$. 
Table 2. Comparison of Pinacocoleps pulcher with congeneric and conspecific

\begin{tabular}{|c|c|c|c|c|c|c|c|c|}
\hline Species & $\begin{array}{l}\text { Body shape on } \\
\text { broad side }\end{array}$ & $\begin{array}{l}\text { Body cross } \\
\text { section }\end{array}$ & $\begin{array}{l}\text { Body length, } \\
\text { in vivo }(\mu \mathrm{m})\end{array}$ & $\begin{array}{l}\text { Contractile } \\
\text { vacuole }\end{array}$ & $\begin{array}{l}\text { Number } \\
\text { of main plate } \\
\text { teeth }\end{array}$ & $\begin{array}{l}\text { Number } \\
\text { of ciliary rows }\end{array}$ & $\begin{array}{l}\text { Number } \\
\text { of spines }\end{array}$ & References \\
\hline P. pulcher & $\begin{array}{l}\text { Ellipsoidal, } \\
\text { pillow-like }\end{array}$ & Ellipsoidal & $80-90$ & Present & $\begin{array}{l}\text { AMP: about } 8 \\
\text { PMP: about } 7\end{array}$ & $18-24$ & $\begin{array}{l}\text { AS: about } 7 \\
\text { PS: about } 7\end{array}$ & Present work \\
\hline P. pulcher & $\begin{array}{l}\text { Flattened } \\
\text { and truncated } \\
\text { ellipsoidal }\end{array}$ & Flattened oval & $80-100$ & Absent & - & $18-20$ & $\begin{array}{l}\text { AS: } 5 \\
\text { PS: } 7\end{array}$ & Spiegel 1926 \\
\hline P. pulcher & Long oval & Oval & $80-100$ & Absent & $\begin{array}{l}\text { AMP: } 10 \\
\text { PMP: } 10\end{array}$ & $20-22$ & $\begin{array}{l}\text { AS: } 6 \\
\text { PS: } 7\end{array}$ & Kahl 1930 \\
\hline P. pulcher & $\begin{array}{l}\text { Broadly rounded- } \\
\text { at the end, } \\
\text { ellipsoidal }\end{array}$ & & $70-110$ & Present & - & $17-22$ & $\begin{array}{l}\text { AS: } 4^{*} \\
\text { PS: } 6^{*}\end{array}$ & Borror 1963 \\
\hline P. arenarius & Rectangular & Flattened & $70-75$ & Present & $\begin{array}{l}\text { AMP: } 3 \\
\text { PMP: } 3\end{array}$ & ca. $25^{*}$ & $\begin{array}{l}\text { AS: } 2 \\
\text { PS: } 10\end{array}$ & $\begin{array}{l}\text { Bock 1952; Lu } \\
\text { et al. } 2013\end{array}$ \\
\hline P. heteracanthus & $\begin{array}{l}\text { Long oval } \\
\text { shaped }\end{array}$ & - & $74-86$ & Present & $\begin{array}{l}\text { AMP: 9-11 } \\
\text { PMP: 7-9 }\end{array}$ & ca. $22 *$ & AS: 2 & Noland 1937 \\
\hline P. incurvus & $\begin{array}{l}\text { Curved } \\
\text { cylindrical }\end{array}$ & Semicircular & $65-80$ & Present & $\begin{array}{l}\text { AMP: } 7 \\
\text { PMP: } 7\end{array}$ & $10-11$ & $\begin{array}{l}\text { AS: } 5 \\
\text { PS: } 3\end{array}$ & $\begin{array}{l}\text { Kahl 1930; Lu et } \\
\text { al. } 2013\end{array}$ \\
\hline P. similis & $\begin{array}{l}\text { Ovoid to } \\
\text { barrel-shaped }\end{array}$ & Circular & $55-65$ & Present & $\begin{array}{l}\text { AMP: } 5 \\
\text { PMP: } 4\end{array}$ & 15 & $\begin{array}{l}\text { AS: } 3 * * \\
\text { PS: } 5-7\end{array}$ & Chen et al. 2010 \\
\hline P. spiralis & Barrel-shaped & - & ca. 50 & - & $\begin{array}{l}\text { AMP: } 7-8 \\
\text { PMP: } 5-6\end{array}$ & ca. 23 & $\begin{array}{l}\text { AS: } 1^{*} \\
\text { PS: } 3^{*}\end{array}$ & Noland 1937 \\
\hline P. tesselatus & $\begin{array}{l}\text { Long } \\
\text { oval-shaped }\end{array}$ & Circular & $75-85$ & Present & $\begin{array}{l}\text { AMP: } 3 \\
\text { PMP: } 3\end{array}$ & $21-23$ & $\begin{array}{l}\text { AS: } 2 \\
\text { PS: } 3\end{array}$ & Lu et al. 2013 \\
\hline
\end{tabular}

Data for the taxon studied in this paper are shown in bold font. - not mentioned, * - data from drawings, ** - data from photographs, AMP - anterior main plate, PMP - posterior main plate, AS - anterior spine, PS - posterior spine.

In the phylogenetic analyses (Fig. 4), P. pulcher strongly supports a sister relationship with the Apocoleps clade (posterior probability of 0.99 , bootstrap value of $85 \%$ ). However, the genus Pinacocoleps did not show a monophyletic relationship with $P$. tesselatus (KC349950) (posterior probability of 0.82 , bootstrap value of $47 \%)$.

\section{DISCUSSION}

\section{Comparison with previous studies and congeners (Table 2)}

Pinacocoleps pulcher (Spiegel, 1926) Foissner et al., 2008 has been collected from saline water and described several times (Kahl 1930; Noland 1937; Borror 1963; Hartwig 1973). However, P. pulcher has never been redescribed using standard methods. Foissner et al. (2008) resurrected the genus Pinacocoleps and transferred Coleps pulcher to the genus Pinacocoleps.
The original population of $P$. pulcher from Germany was described and characterized as organisms with a flattened, oval body, $80-100 \mu \mathrm{m}$ in length, with $18-20$ rows of armor plates, and distinct anterior and posterior spines, dwelling in marine habitats (Table 2; Fig. 1H; Spiegel 1926). The Korean and the original population are morphologically identical. However, the number of teeth was not comparable because the armor tiers were not distinguished in the original population (Spiegel 1926). The Korean population differs slightly from the other German populations in the number of teeth on the anterior (eight vs. ten) and the posterior (five vs. ten) main plates (Table 2; Fig. 1I; Kahl 1930).

Pinacocoleps pulcher differs from its related species P. heteracanthus (Noland, 1937) in body shape (pillowlike vs. cylindrical) and arrangement of anterior spines (located on either slender sides vs. one side) (Table 2; Fig. 1J; Noland, 1937). Another related species $P$. arenarius (Bock, 1952) can be separated from P. pulcher by body outline (rectangular vs. ellipsoidal), body size (70-75 $\mu \mathrm{m}$ vs. $80-100 \mu \mathrm{m})$ and number of anterior 


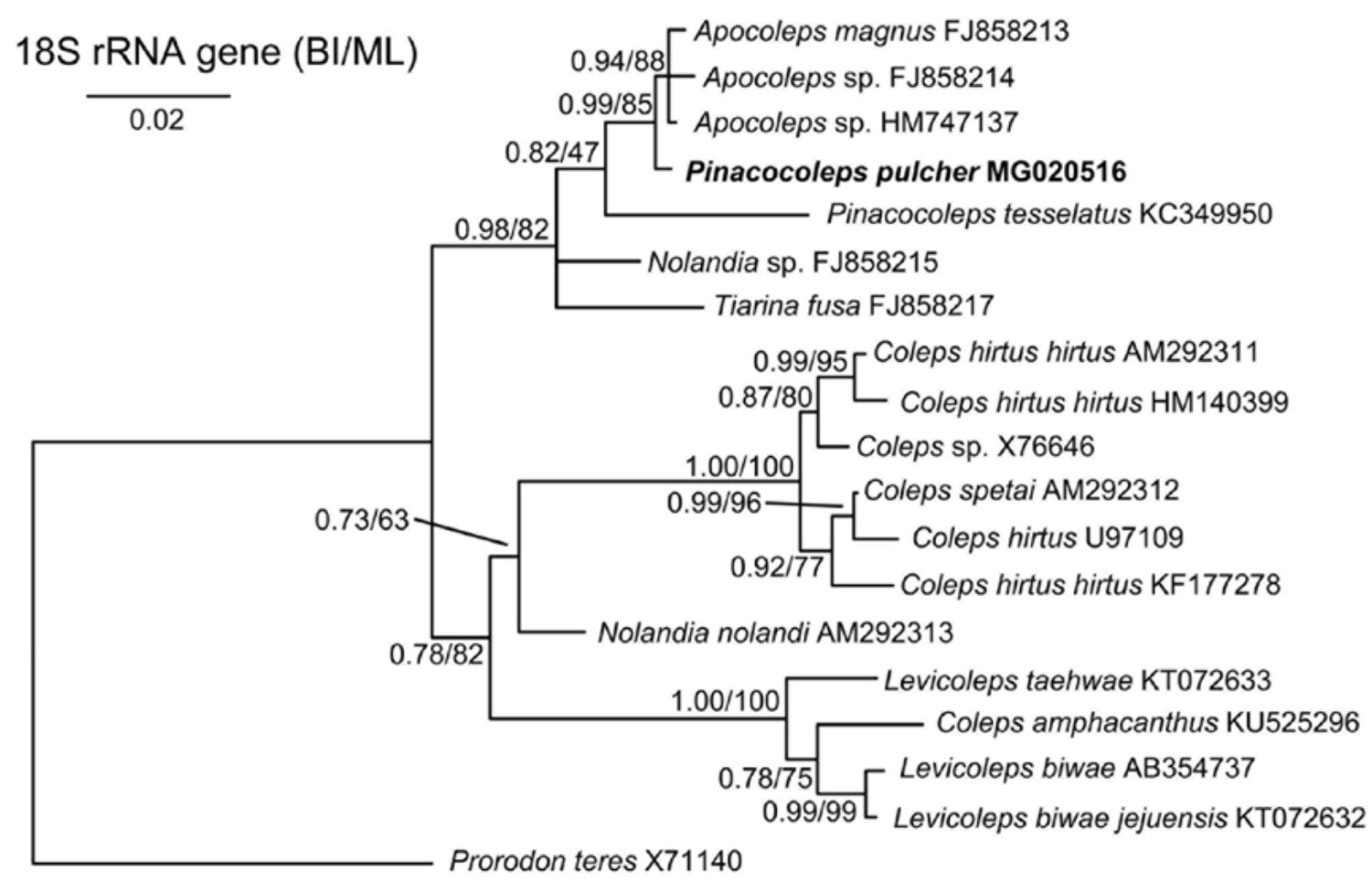

Fig. 4. Bayesian inference (BI) phylogenetic tree based on nuclear SSU rRNA gene sequences of Pinacocoleps pulcher and Colepidae species. Posterior probabilities of Bayesian inference (BI) and bootstrap values of maximum likelihood (ML) are shown for interior branches. A dash indicates a mismatch in branching pattern. The species sequenced in this study is indicated in bold font. The scale bar corresponds to two substitutions per 100 nucleotide positions.

spines (one vs. about seven), (Table 2; Fig. 1K; Bock 1952; Lu et al. 2013).

In addition, $P$. pulcher and $P$. spiralis (Noland, 1937) were distinguished using body shape (pillow-like vs. barrel-like), body length (80-100 $\mu \mathrm{m}$ vs. approximately $50 \mu \mathrm{m}$ ), arrangement of somatic ciliary rows (vertical vs. spiral), the number of anterior spines (about seven vs. one in drawing), and the number of posterior spines (about seven vs. three in drawing). Pinacocoleps pulcher and P. tesselatus (Kahl, 1930) differ in body shape (pillow-like vs. cylindrical to oval), the number of anterior (about seven vs. two) and posterior spines (about seven vs. three), the number of anterior (eight vs. three) and posterior main plate teeth (five vs. three) (Table 2; Kahl 1930; Lu et al. 2013). Pinacocoleps pulcher can be distinguished from P. similis (Kahl, 1933) in body cross-section (ellipsoidal vs. circular), body length $(80-100 \mu \mathrm{m}$ vs. 55-65 $\mu \mathrm{m})$, and the number of anterior main plate teeth (eight vs. five) (Table 2; Kahl 1933; Chen et al. 2010).

\section{Phylogeny}

In the phylogenetic analysis, $P$. pulcher did not cluster with $P$. tesselatus (genetic distance of $2.8 \%$ ). By contrast, $P$. pulcher showed a sister relationship with the Apocoleps clade (genetic distances of $0.2-0.4 \%$ ). Pinacocoleps pulcher differs from Apocoleps by the number of tiers (six vs. eight) and the plate window (absent vs. present; Chen et al. 2009). Based on the phylogenetic tree, it could be assumed that the number of tiers and the presence/absence of plate window might not be useful characters for distinguishing between the genera. However, this result was analyzed using only two species among the seven species of Pinacocoleps. Therefore, the addition of molecular genetic data and subsequent studies are necessary. Similarly, for other genera in Colepidae (Coleps and Nolandia) that are non-monophyletic, further studies are necessary (Chen et al. 2016; Lu et al. 2016). 
Acknowledgements. This work was supported by grants from the National Institute of Biological Resources (NIBR), funded by the Ministry of Environment (MOE) of the Republic of Korea (NIBR201601201); the National Research Foundation of Korea (NRF) funded by the Korea government (MSIP; Ministry of Science, ICT \& Future Planning) (No. NRF-2017R1C1B5017183); and the Korea Polar Research Institute (KOPRI, grant no. PE17900).

\section{REFERENCES}

Bock K. J. (1952) Über einige holo- und spirotriche Ciliaten aus den marinen Sandgebieten der Kieler Bucht. Zool. Anz. 149: $107-115$

Borror A. C. (1963) Morphology and ecology of the benthic ciliated protozoa of Alligator Harbor, Florida. Arch. Protistenk. Bd. 106: $465-534$

Chen X., Warren A., Song W. (2009) Taxonomic studies on a new marine ciliate, Apocoleps magnus gen. nov., spec. nov. (Ciliophora, Colepidae), isolated from Qingdao, China. J. Ocean Univ. China 8: 317-321

Chen X., Wang Y., Long H., Al-Rasheid, K. A. S., Warren A., Song W. (2010) Mphological studies on two marine colepid ciliates from Qingdao, China, Nolandia orientalis spec. nov. and Pinacocoleps similis (Kahl, 1933) comb. nov. (Ciliophora, Colepidae). Eur. J. Protistol. 46: 254-262

Chen X., Shazib S. U. A., Kim J. H., Jang S. W., Shin M. K. (2016). Morphological description and molecular phylogeny of two species of Levicoleps (Ciliophora, Prostomatida), L. taehwae nov. spec. and L. biwae jejuensis nov. subspec., collected in Korea. J. Eukaryot. Microbiol. 63: 471-480

Darriba D., Taboada G. L., Doallo R., Posada D. (2012) jModel Test2: more models, new heuristics and parallel computing. Nat. Methods 9: 772

Diesing K. M. (1865) Revision der Prothelminthen. Abtheilung: Amastigen. I. Amastigen ohne Peristom. Sber. Akad. Wiss. Wien. 52: 505-579

Foissner W. (2014) An update of 'basic light and scanning electron microscopic methods for taxonomic studies of ciliate protozoa' Int. J. Syst. Evol. Microbiol. 64: 271-292

Foissner W., Kusuoka Y., Shimano S. (2008) Morphology and gene sequence of Levicoleps biwae n. gen., n. sp. (Ciliophora, Prostomatida), a proposed endemic from the ancient Lake Biwa, Japan. J. Eukaryot. Microbiol. 55: 185-200

Hartwig E. (1973) Die Ciliaten des Gezeiten-Sandstrandes der Nordseeinsel Sylt. I. Systematik. Abh. math-naturw. Kl. Akad. Wiss. Mainz. Mikrofauna Meer. 18: 1-69
Kahl A. (1930) Urtiere oder Protozoa I: Wimpertiere order Ciliata (Infusoria) 1. Allegemeiner Teil und Prostomata. Tierwelt Dtl. 18: $1-180$

Kahl A. (1933) Ciliata Libera et Ectocommensalia. Tierwelt Nordund Ostsee 23 (Teil II, c c $_{3}$ : 29-146

Kearse, M., Moir, R., Wilson, A., Stones-Havas, S., Cheung, M., Sturrock, S., Buxton, S., Cooper, A., Markowitz, S., Duran, C., Thierer, T., Ashton, B., Mentjies, P., Drummond, A. (2012) Geneious Basic: an integrated and extendable desktop software platform for the organization and analysis of sequence data. Bioinformatics 28: 1647-1649.

Lu B., Huang J., Chen X. (2013) The morphology and SSU rRNA gene sequence analysis of a poorly-known brackish water ciliate, Pinacocoleps tesselatus (Kahl, 1930) (Ciliophora, Colepidae) from Hangzhou Bay, China. Zootaxa 3637: 123-130

Lu B., Ma M., Gao F., Shi Y., Chen X. (2016) Morphology and molecular phylogeny of two colepid species from China, Coleps amphacanthus Ehrenberg, 1833 and Levicoleps biwae jejuensis Chen et al., 2016 (Ciliophora, Prostomatida). Zoological Research 37: 176-185

Lynn D. H. (2008) The ciliated Protozoa: characterization, classification, and guide to the literature, 3rd edn. Springer, Dordrecht

Nguyen L., Schmidt H. A., Haeseler A., Minh B. Q. (2015) IQTREE: a fast and effective stochastic algorithm for estimating maximum likelihood phylogenies. Mol. Biol. Evol. 32: 268-274

Noland L. E. (1937) Observations on marine ciliates of the Gulf Coast of Florida. Trans. Am. Micros. Soc. 56: 160-171

Pan X., Bourland W. A., Song W. (2013) Protargol Synthesis: An In-house Protocol. J. Eukaryot. Microbiol. 60: 609-614

Ronquist F., Teslenko M., van der Mark P., Ayres D. L., Darling A., Hohna S., Larget B., Liu L., Suchard M. A., Huelsenbeck J. P. (2012) MrBayes 3.2: efficient Bayesian phylogenetic inference and model choice across a large model space. Syst. Biol. 61: $539-542$

Spiegel A. (1926) Einige neue marine Ciliaten. Arch. Protistenkd. 55: $184-190$

Tamura K., Peterson D., Peterson N., Stecher G., Nei M., Kumar S. (2011) MEGA5: molecular evolutionary genetics analysis using maximum likelihood, evolutionary distance, and maximum parsimony methods. Mol. Biol. Evol. 28: 2731-2739

Received on $15^{\text {th }}$ June, 2017; revised on $26^{\text {th }}$ September, 2017; accepted on $26^{\text {th }}$ September, 2017 